WSRC-TR-99-00239

Revision 0

July 20, 1999

\begin{abstract}
KEY WORDS: Permeability
Waste Treatment

Portland Cement
\end{abstract}

Retention: Permanent

PERMEABILITY OF CONSOLIDATED INCINERATOR FACILITY WASTES STABILIZED WITH PORTLAND CEMENT (U)

\author{
Author \\ B. W. WALKER, \\ Westinghouse Savannah River Company \\ Savannah River Technology Center, \\ Aiken, SC 29808
}

Date: July 20, 1999

Westinghouse Savannah River Company

Savannah River Site

Aiken, SC 29808

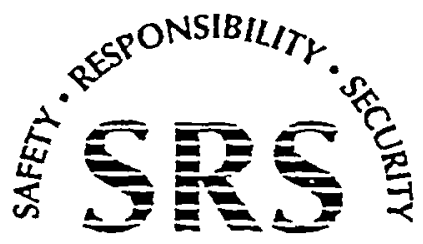




\section{Permeability of Consolidated Incinerator Facility Wastes Stabilized with Portland Cement}

by

B. W. Walker

Westinghouse Savannah River Company

Savannah River Site

Aiken, South Carolina 29808

DOE Contract No. DE-AC09-96SR18500

This paper was prepared in connection with work done under the above contract number with the U.S.

Department of Energy. By acceptance of this paper, the publisher and/or recipient acknowledges the U. S. Government's right to retain a nonexclusive, royalty-free license in and to any copyright covering this paper, along with the right to reproduce and to authorize others to reproduce all or part of the copyrighted paper. 


\section{DISCLAIMER}

Portions of this document may be illegible in electronic image products. Images are produced from the best available original document. 


\section{DISCLAIMER}

This report was prepared as an account of work sponsored by an agency of the United States Government. Neither the United States Government nor any agency thereof, nor any of their employees, makes any warranty, express or implied, or assumes any legal liability or responsibility for the accuracy, completeness, or usefulness of any information, apparatus, product, or process disclosed, or represents that its use would not infringe privately owned rights. Reference herein to any specific commercial product, process, or service by trade name, trademark, manufacturer, or otherwise does not necessarily constitute or imply its endorsement, recommendation, or favoring by the United States Government or any agency thereof. The views and opinions of authors expressed herein do not necessarily state or reflect those of the United States Government or any agency thereof.

This report has been reproduced directly from the best available copy.

Available to DOE and DOE contractors from the Office of Scientific and Technical Information, P. O. Box 62, Oak Ridge, TN 37831; prices available from (423) 576-8401.

Available to the public from the National Technical Information Service, U. S. Department of Commerce, 5285 Port Royal Road, Springfield, VA 22161. 
KEY WORDS: Permeability

Waste Treatment

Portland Cement

RETEntion: Permanent

\title{
PERMEABILITY OF CONSOLIDATED INCINERATOR FACILITY WASTES STABILIZED WITH PORTLAND CEMENT (U)
}

\author{
Author \\ B. W. WALKER, \\ Westinghouse Savannah River Company \\ Savannah River Technology Center, \\ Aiken, SC 29808
}

Date: July 20, 1999

Westinghouse Savannah River Company

Savannah River Site

Aiken, SC 29808

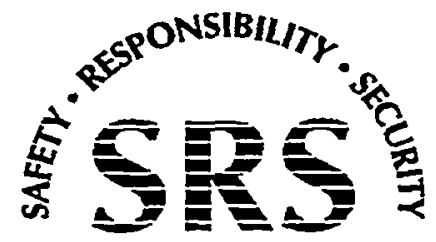


WSRC-TR-99-00239

Revision 0

July 20, 1999

\section{REVIEWS AND APPROVALS}

\section{Author}

D. U. G/atken

$7-29-99$

B. W. Walker, Author

Date

Waste Processing Technology

\section{Approvals/Review}

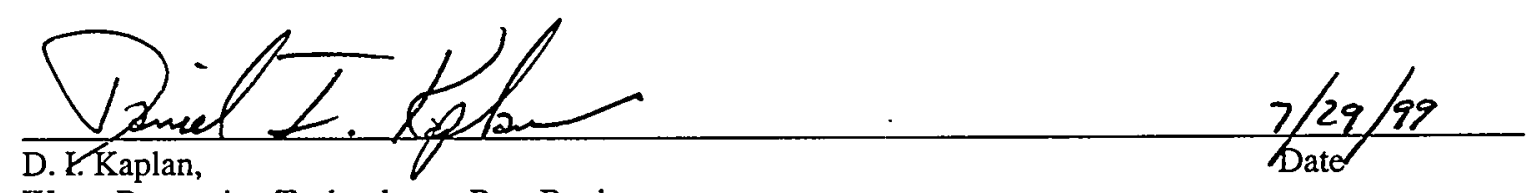

Waste Processing Technology: Peer Review

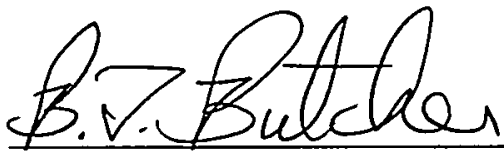

B. T. Butcher, Level 4

Waste Processing Technology

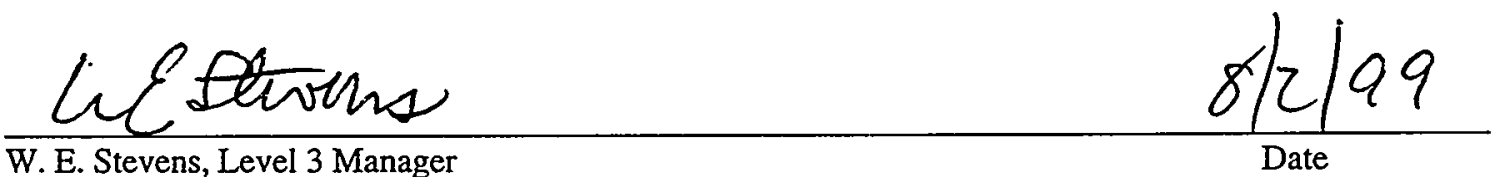

W. E. Stevens, Level 3 Manager

Waste Processing Technology

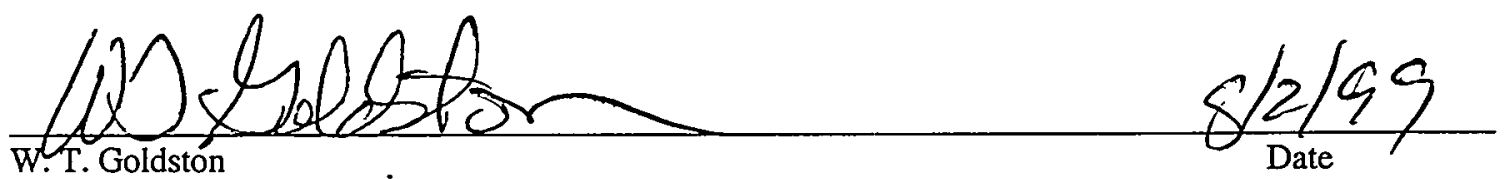

SW Integration and Integration

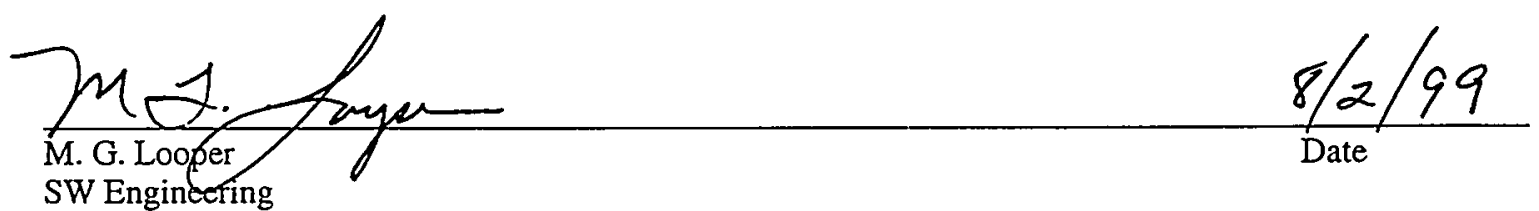




\section{TABLE OF CONTENTS}

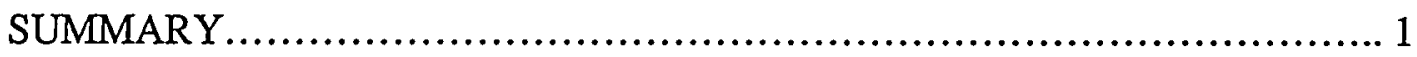

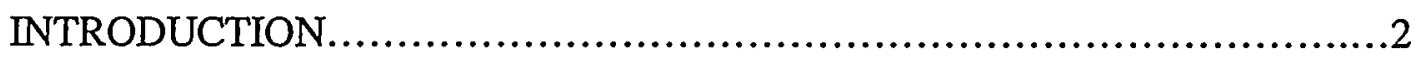

EXPERIMENTAL

Sample Preparation and Curing............................................. 3

ELE Falling Head Method............................................6

UFA Centrifuge Method.............................................9

RESULTS

Permeability Results.................................................11

Compressive Strength.............................................. 11

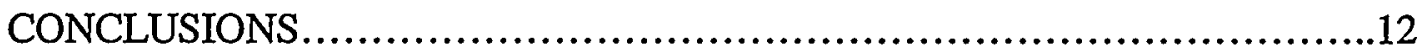

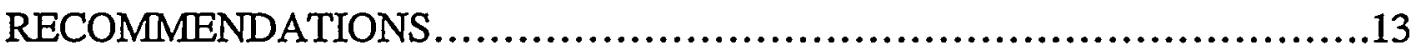

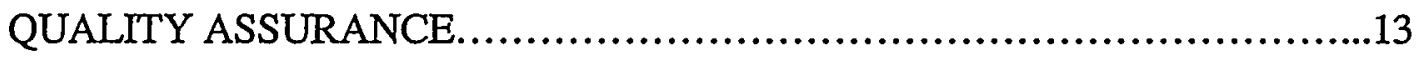

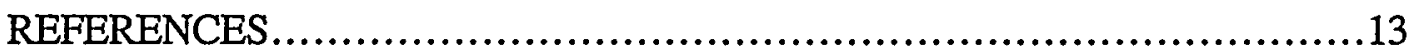

\section{TABLES}

Table I. Test Matrix........................................................4

Table II. Waste Form Component Proportions..............................5

Table III. Waste Form Permeabilities....................................11

\section{FIGURES}

Figure 1. ELE Permeameter........................................... 7

Figure 2. Permeameter Schematic.......................................... 8

Figure 3. Centrifuge Internal Parts..................................... 10

Figure 4. Picture of UFA Centrifuge......................................10

\section{APPENDICES}

Appendix 1. Characterization of Incinerator Waste..........................A1

Appendix 2. Permeabililty Calculations for Waste Forms....................A2

Appendix 3. ELE Permeability Procedure...............................A3 


\section{SUMMARY}

The Consolidated Incinerator Facility (CIF) at the Savannah River Site (SRS) burns low-level radioactive wastes and mixed wastes as a method of treatment and volume reduction. The CIF generates secondary waste, which consists of ash and off-gas scrubber solution. Currently the ash is stabilized/solidified in the Ashcrete process. The scrubber solution (blowdown) is sent to the SRS Effluent Treatment Facility (ETF) for treatment as waste water. In the past, the scrubber solution was also stabilized/solidified in the Ashcrete process as blowcrete and will continue to be treated this way for listed waste burns and scrubber solution that do not meet the Effluent Treatment Facility (ETF) Waste Acceptance Criteria (WAC).

The disposal plan for Ashcrete and special case blowcrete is to bury it in shallow unlined trenches in E-Area. The WAC for intimately mixed cement-based waste forms intended for direct disposal specifies: 1) a minimum compressive strength of $500 \mathrm{psi}$, and 2) a saturated hydraulic conductivity, or permeability, of less than $1 \times 10^{-8} \mathrm{~cm} / \mathrm{sec}$.

Simulated waste and actual CIF ash and scrubber solution were mixed in the laboratory and cast into forms for testing. The compressive strengths of the samples. were approximated by using a concrete penetration instrument. The permeability was measured by two different methods, a falling head method conducted at the Savannah River Technical Center (SRTC) and a whole body centrifuge method conducted by UFA Ventures.

Non radioactive samples were used to establish a correlation between the falling head and whole body centrifuge permeability results. Results obtained by the centrifuge method were one order of magnitude higher (10x more permeable) than those obtained by the falling head method.

Results from correlations derived for the centrifuge method indicate that Ashcrete meets the permeability requirements in the E-Area WAC but Blowcrete made with $1 \mathrm{wt}$. \% total solids scrubber solution from burning Purex waste does not. These samples meet the compressive strength requirement for trench disposal.

Blowcrete prepared with concentrated Purex $40 \mathrm{wt}$. \% total solids scrubber solution had a permeability of $3.8 \times 10^{-8} \mathrm{~cm} / \mathrm{s}$ when the measurement was made by the SRTC falling head method which does not meet the permeability requirement of $1 \times 10^{-8} \mathrm{~cm} / \mathrm{s}$. This radioactive sample waste form was not tested by the centrifuge method but if the correlation developed from other samples is applied, it would not meet the $1 \times 10^{-8} \mathrm{~cm} / \mathrm{s}$ requirement. The $40 \mathrm{wt}$. \% total solids waste form meets the compressive strength requirement for trench disposal.

The data reported above were obtained for waste forms mixed under laboratory conditions. An ashcrete sample collected from the plant Ashcrete Facility and tested by the falling head method met permeability requirements using the $10 x$ correlation to estimate centrifuge method results. 
The centrifuge method results indicate the samples are more permeable than the falling head method. This is probably due to the centrifuge method causing a greater degree of saturation, plugging of pores by glue application to the sample in the falling head method, or because of greater force being applied in the centrifuge method. Either method of measuring permeability is acceptable for qualifying the CIF ashcrete and blowcrete for E-Area disposal. Currently there is no vendor available to handle solid radioactive samples. If the centrifuge method is not available for testing then the correlation relating centrifuge permeabilities to falling head permeabilities could be used to guarantee permeability results are acceptable.

\section{INTRODUCTION}

Disposal plans for the CIF Ashcrete and Blowcrete depend on whether the waste burned in the incinerator is listed hazardous/mixed, characteristically hazardous/mixed, or radioactive. At the present time, SRS does not have an on-site disposal facility for listed hazardous/mixed waste even if the waste is treated and the resulting waste form passes the TCLP leaching requirements. An example of this type of waste/waste form is the Ashcrete and Blowcrete resulting from burning the M-Area Filter Paper Take-up Rolls, which carried the F006 listed waste code. Currently the drums of waste form generated in this campaign are stored in M-Area. Off-site disposal at Envirocare is the most probable disposal option.

The disposal plan for Ashcrete and Blowcrete generated from burning characteristically hazardous/mixed waste or low-level radioactive waste is to place the containerized waste forms in an unlined earthen trench in E-Area. The direct trench disposal is an SRS option for lowlevel, non hazardous (acceptable leachability for RCRA toxic metals) intimately mixed cement based waste forms. The WAC for direct trench disposal of cement-based waste forms includes an unconfined compressive strength requirement of greater than 500 psi and a permeability of less than $1 \times 10^{-8} \mathrm{~cm} / \mathrm{sec} .^{1}$ The E-Area WAC is based on the contaminant transport modeling in the E-Area Disposal Facility Performance Assessment ${ }^{2}$.

Determination of permeability is difficult for samples, which have low values. This is due, in part, to difficulty in:

1. measuring very small volumes of water flowing through an impermeable material

2. reducing the sample thickness to achieve flow in a shorter time. (Thin disks are fragile and in many case contain pores, aggregate, salt crystals, ash particles)

3. achieving complete saturation.

In addition, there are no standard low permeable materials available from the National Institute of Standards and Testing (NIST) or from equipment vendors, which can be used to calibrate or verify measurements.

Consequently, two different techniques were applied to the CIF waste forms. Given the limited testing, results obtained by both instruments are considered valid since the techniques require different conditions for measuring permeability. For example, a force pressure of $10 \mathrm{psi}$ was used in the falling head method whereas a gravitational force of up to $20,000 \mathrm{~g}$ was used in the centrifuge method. Both the hydraulic conductivity values and the samples themselves are affected by the magnitude of the forces applied during the measurement. 
Waste Processing Technology (WPT) personnel at SRTC were requested to use an ELE Permeameter, which was available in the CIF Laboratory to perform the permeability measurements. In order to use this instrument, parts had to be ordered, the instrument set up and tested, and a procedure written. The procedure is included in Appendix 3. This instrument is similar to the one described for ASTM D2434-68. In ASTM D2434-68 a constant low pressure head (constant head test) is used to determine permeability of high permeability materials such as sand or gravel. The ELE instrument is a modified version of this method called a falling head test which uses a relatively high pressure to determine permeabilities of low permeability materials such as rock or cement.

Duplicate samples made with non radioactive simulants were sent to UFA Ventures, Richland, WA for testing using a centrifuge method. An ASTM test method is being developed for the centrifuge method of measuring unsaturated and saturated permeability.

Compressive strength is usually performed by using a mechanical press to crush samples. The amount of force needed to cause the sample to fail is recorded and related to the area. However, mixing several liters of radioactive waste form necessary for preparation of the compressive strength samples for this determination was beyond the scope of this effort, which was performed in a small low-level radioactive hood. Consequently, a method was developed to determine compressive strength using a penetration instrument from Gilson Inc. Using this instrument it is possible to determine if a known amount of surface area of a waste form will resist cracking when placed under a pressure of greater than the 500 psi required by the WAC. In this study we submitted samples to a force of $700 \mathrm{psi}$.

Characterization data of the Purex ash and blowdown used to make the samples is presented in Appendix 1.

\section{EXPERIMENTAL PROCEDURE}

\section{Sample Preparation and Curing}

Two non radioactive mixtures were prepared with Portland cement and a 10 and $30 \mathrm{wt} \%$ $\mathrm{NaCl}$ solution for the purpose of learning to use the ELE instrument and to send to UFA Ventures for measurement of permeability using the centrifuge method. These formulations were cast into several sample containers which were sealed for curing.

Three waste forms were also prepared in a radioactive hood using actual CIF blowdown (dilute and concentrated) and ash. Samples were cast in plastic containers and sealed for curing at ambient room temperature for 28 days. No radioactive samples were sent for off-site testing.

All samples were mixed by hand stirring with a spatula in a plastic beaker for 10 minutes. Ingredients in the five formulations prepared for this study are listed in Table I. The weight per cents of different components are shown in Table II. 
Table I. Waste forms prepared for Permeability Testing.

\begin{tabular}{|c|c|c|c|c|c|c|c|c|}
\hline $\begin{array}{l}\text { Sample } \\
\text { No. }\end{array}$ & $\begin{array}{l}\text { Sample } \\
\text { Descrip. }\end{array}$ & $\begin{array}{l}\mathrm{PC} \\
\mathrm{Wt} \\
(\mathrm{g})\end{array}$ & $\begin{array}{l}\text { Add. } \\
\mathrm{H}_{2} \mathrm{O} \\
W \mathrm{t} \\
\text { (g) }\end{array}$ & $\begin{array}{l}\text { Sim. } \\
10 \text { wt \% } \\
\mathrm{NaCl} \\
\text { (g) }\end{array}$ & $\begin{array}{l}\text { Sim. } \\
30 \text { wt \% } \\
\mathrm{NaCl} \\
\text { (g) }\end{array}$ & $\begin{array}{l}\text { Scrub. } \\
\text { Soln } \\
1 \text { wt \% } \\
(g)\end{array}$ & $\begin{array}{l}\text { Scrub. } \\
\text { Soln. } \\
40 \text { wt \% } \\
\text { (g) }\end{array}$ & $\begin{array}{l}\text { Dry } \\
\text { Purex } \\
\text { Ash } \\
\text { (g) }\end{array}$ \\
\hline 1 & $\begin{array}{l}\text { Simulant } \\
\text { With } 10 \mathrm{Wt} \% \\
\mathrm{NaCl}\end{array}$ & 100 & - & 46 & - & - & - & - \\
\hline 2 & $\begin{array}{l}\text { Simulant } \\
\text { With } 30 \mathrm{Wt} \% \\
\mathrm{NaCl}\end{array}$ & 100 & - & - & 59 & - & - & - \\
\hline 3 & $\begin{array}{l}\text { Purex blowcrete } \\
\text { With } 1 \text { wt \% } \\
\text { Solids }\end{array}$ & 87 & - & - & - & 63 & - & - \\
\hline 4 & $\begin{array}{l}\text { Purex blowcrete } \\
\text { With } 40 \text { wt \% } \\
\text { Solids }\end{array}$ & 97 & - & - & - & - & 60 & - \\
\hline 5 & Purex ashcrete & 110 & 111 & - & - & - & - & 42 \\
\hline 6 & $\begin{array}{l}\text { Plant Purex } \\
\text { Ashcrete }\end{array}$ & 114.4 & 100 & - & - & - & - & 100 \\
\hline
\end{tabular}


Table II. Waste Form Component Proportions.

\begin{tabular}{|c|c|c|c|c|c|c|}
\hline $\begin{array}{l}\text { Sample } \\
\text { No. }\end{array}$ & $\begin{array}{l}\text { Sample } \\
\text { Descrip. }\end{array}$ & $\begin{array}{l}\text { Portland } \\
\text { Cement } \\
\text { (wt \%) }\end{array}$ & $\begin{array}{l}\text { Water } \\
\text { (wt \%) }\end{array}$ & $\begin{array}{l}\mathrm{NaCl} \\
\text { (wt \%) }\end{array}$ & $\begin{array}{l}\text { Purex } \\
\text { Scrubber } \\
\text { Solids } \\
\text { (wt \%) }\end{array}$ & $\begin{array}{l}\text { Dry } \\
\text { Purex } \\
\text { Ash } \\
\text { (wt \%) }\end{array}$ \\
\hline 1 & $\begin{array}{l}\text { Simulant } \\
\text { With } 10 \mathrm{Wt} \% \\
\mathrm{NaCl}\end{array}$ & 68.4 & 28.4 & 3.2 & - & - \\
\hline 2 & $\begin{array}{l}\text { Simulant } \\
\text { With } 30 \mathrm{Wt} \% \\
\mathrm{NaCl}\end{array}$ & 62.9 & 26.0 & 11.1 & - & - \\
\hline 3 & $\begin{array}{l}\text { Purex blowcrete } \\
\text { With } 1 \mathrm{wt} \% \\
\text { Solids }\end{array}$ & 58.0 & 41.6 & - & 0.4 & - \\
\hline 4 & $\begin{array}{l}\text { Purex blowcrete } \\
\text { With } 40 \text { wt } \% \\
\text { Solids }\end{array}$ & 61.8 & 22.9 & - & 15.3 & - \\
\hline 5 & Purex ashcrete & 41.8 & 42.2 & - & - & 16.0 \\
\hline 6 & Plant ashcrete & 36.3 & 39.8 & - & - & 23.9 \\
\hline
\end{tabular}

Table II notes: 1) Scrubber solids refer to total solids in the solution. 2) Initially the ash contained close to 25 weight $\%$ water. The ash amount is reported in this table on a dry basis and the ash water included in the water column.

The samples were cast as cylinders with a diameter of $2.54 \mathrm{~cm}$ and heights varying from about $0.75 \mathrm{~cm}$ to $5 \mathrm{~cm}$. The objective was to cast the samples to fit in the ELE sample holder. The thickness required for the sample depends to some extent on the permeability and inhomogeneity of the material. After demolding, the cylinders were cut into thinner disks if necessary. A hack saw blade was used for this manual operation.

The samples tested in the ELE permeameter were about $0.75 \mathrm{~cm}$ in thickness. The cylindrical samples tested by UFA Ventures, Inc. were $3-4 \mathrm{~cm}$ in height. Samples used to determine the resistance to penetration were cylinders about $5 \mathrm{~cm}$ in height. The penetration tests were performed on the flat top surface of these samples.

A technique was developed to glue the disk-shaped samples into the ELE sample holder. An epoxy resin was used to obtain a secure leak-tight seal between the sample holder and the waste form. Corrosion of the ELE sample holder was observed after the saturation process. This was attributed to the presence of corrosive salts in the CIF blowdown and simulants used to make the waste forms. 
WSRC-TR-99-00239

July 20,1999

Page 6 of 13

Saturation was achieved by applying standing water on the top side of the disk and applying house vacuum on the opposite side of the sample. Saturation of the sample pore spaces was carried out for at least 48 hours. The degree of saturation was not determined during these tests. However, it is recommended for future experiments.

\section{ELE Falling Head Method}

The falling head method of determining permeability is based on Darcy's Law. An ELE permeameter, Model K-670A, was used in these experiments. A picture of the permeameter apparatus is given in Figure 1.

The apparatus consists of a tank, tank manometer, inlet pressure gauge, outlet pressure gauge, pressure regulator, isolation valves, sample holder, two sample holder heads, connection tubing, and a sample head manometer. Appendix 3 contains the SRTC procedure covering details of operation of the apparatus. ${ }^{3}$ A schematic of the experimental apparatus is given in Figure 2.

A disk of a cured waste form is cut and the diameter and thickness of the sample measured. The disk is glued with epoxy resin in a sample holder and allowed to set over night. The sample holder is fastened between two heads on the apparatus which have gasket seals. The difference between the sample buret and tank buret is measured with the tank open to the atmosphere and without pressure and recorded as h1. After buret measurements the tank buret valve is closed and the tank pressurized continuously with air at a known pressure set with a regulator. The inlet pressure and outlet pressure are recorded. Water is forced from a tank through the sample and into a buret at the sample head outlet. The time that it takes to push a known amount of water through the sample is recorded. After flow and time measurements the difference between the sample buret and tank buret is again measured with the tank open to the atmosphere and without pressure and recorded as h2.

The permeability is calculated using the following equation:

$\mathrm{K}=(\mathrm{QxL}) /(\mathrm{AxH})=$ Permeability where

$\mathrm{h}=(\mathrm{h} 1+\mathrm{h} 2) / 2$

$\mathrm{Q}=$ water flow rate in $\mathrm{mls} / \mathrm{sec}$

$\mathrm{L}=$ length of the sample in $\mathrm{cms}$

$A=$ area of sample in $\mathrm{cm}^{2}$

$\mathrm{H}=\left(\mathrm{P}_{\text {in }}-\mathrm{P}_{\text {out }}\right) \times 70.31+\mathrm{h}$

$\mathrm{h} 1$ is the measured distance in centimeters between the top of the tank manometer level and the top of the sample holder manometer when the permeameter is open to the atmosphere before the analysis is performed. $\mathrm{h} 2$ is the measured distance in centimeters between the top of the tank manometer level and the top of the sample holder manometer when the permeameter is open to the atmosphere after the analysis is performed. $P_{\text {in }}$ and $P_{\text {out }}$ units are pounds per square inch (psi). The 70.31 is a factor to convert psi to centimeters in the H equation. 
WSRC-TR-99-00239

July 20,1999

Page 7 of 13

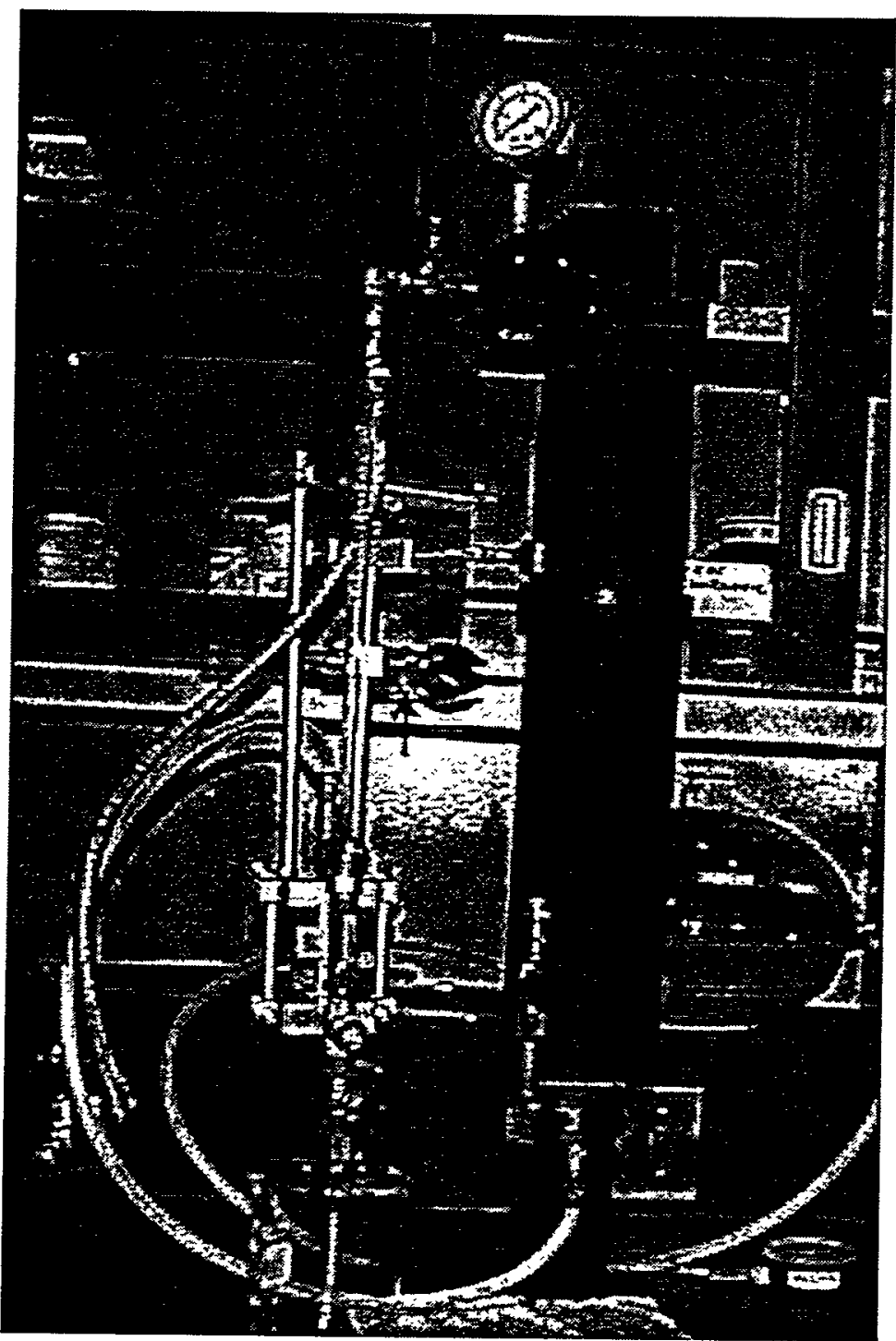

Figure 1. ELE Permeameter 
WSRC-TR-99-00239

July 20,1999

Page 8 of 13

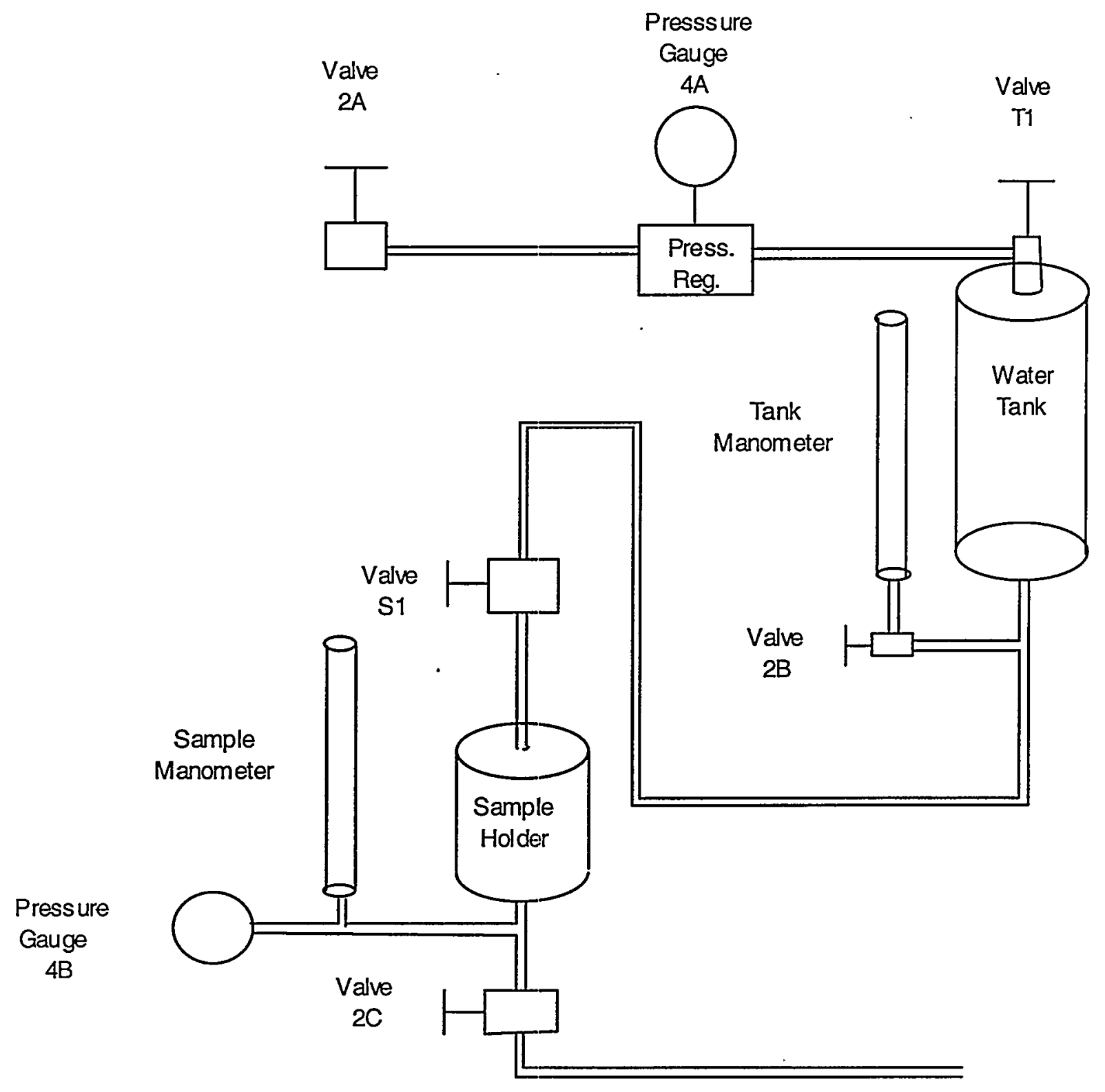

Figure 2. Permeameter Schematic 


\section{UFA Centrifuge Method}

The permeability results using the Falling Head method were compared to results obtained by UFA Ventures with a Centrifuge method on duplicate samples. The centrifuge method is known as an unsaturated flow apparatus (UFA) and is applied to any apparatus that uses open flow centrifugation.

Using a UFA is effective because it allows the operator to set the variables in Darcy's Law. Darcy's Law states that the fluid flux equals the permeability times the fluid driving force. The driving force is fixed by imposing an acceleration on the sample through an adjustable rotation speed. The flux is fixed by setting the flow rate into the sample with an appropriate constant flow pump and dispersing the flow front evenly over the sample. Thus, the sample reaches the steady state permeability, which is dictated by that combined flux and driving force.

A UFA instrument consists of an ultracentrifuge with a constant, ultra-low flow pump that provides fluid to the sample surface through a rotating seal assembly and microdispersal system. The apparatus can reach accelerations of up to $20,000 \mathrm{~g}$, temperatures can be adjusted from -20 degrees to 150 degrees $\mathrm{C}$. Effluent from the sample is collected in a transparent, volumetrically calibrated chamber at the bottom of the sample assembly. A diagram of centrifuge internal parts is shown in Figure 3 and a picture of the instrument is shown in Figure 4. 


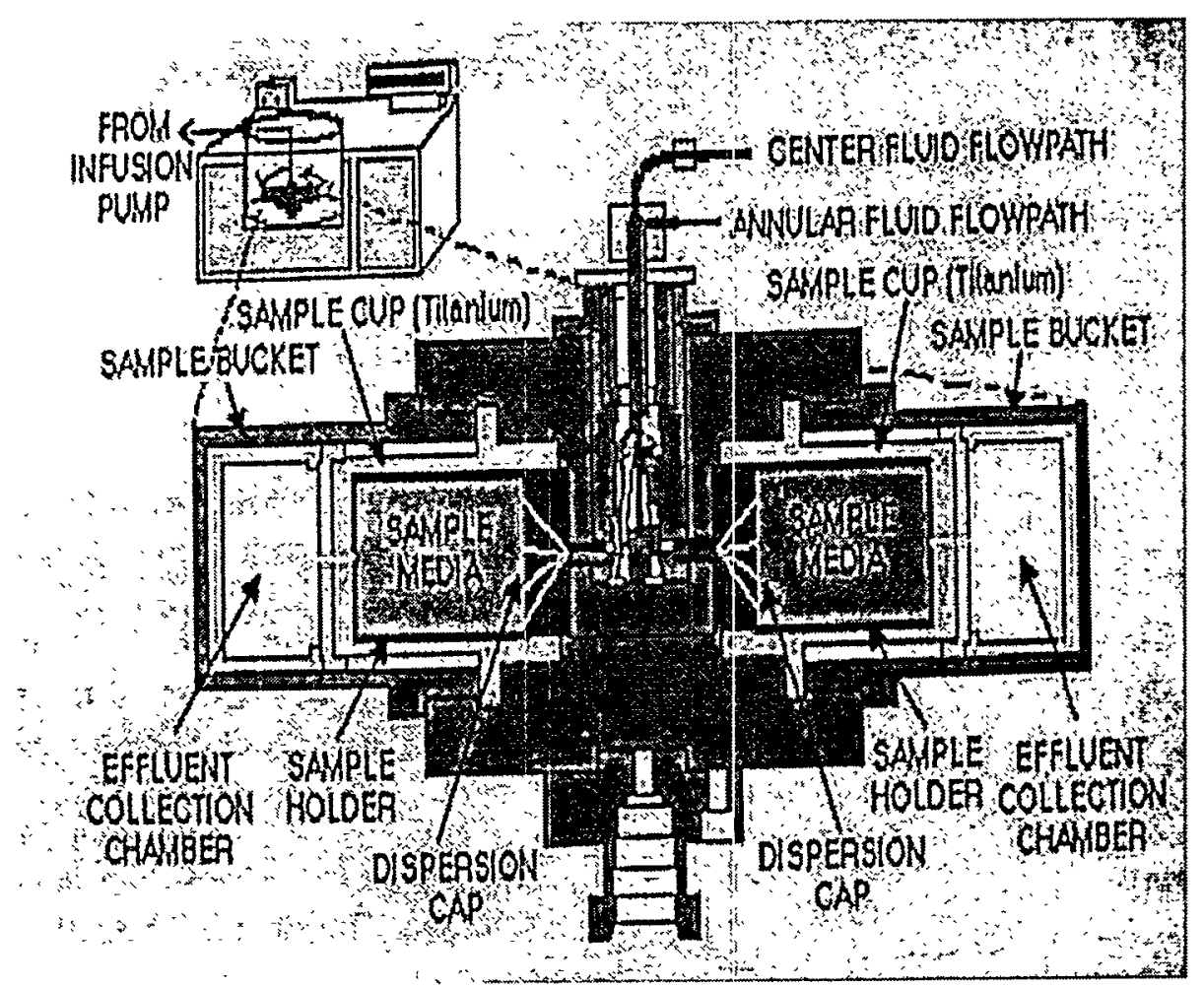

Figure 3. Centrifuge Internal Parts

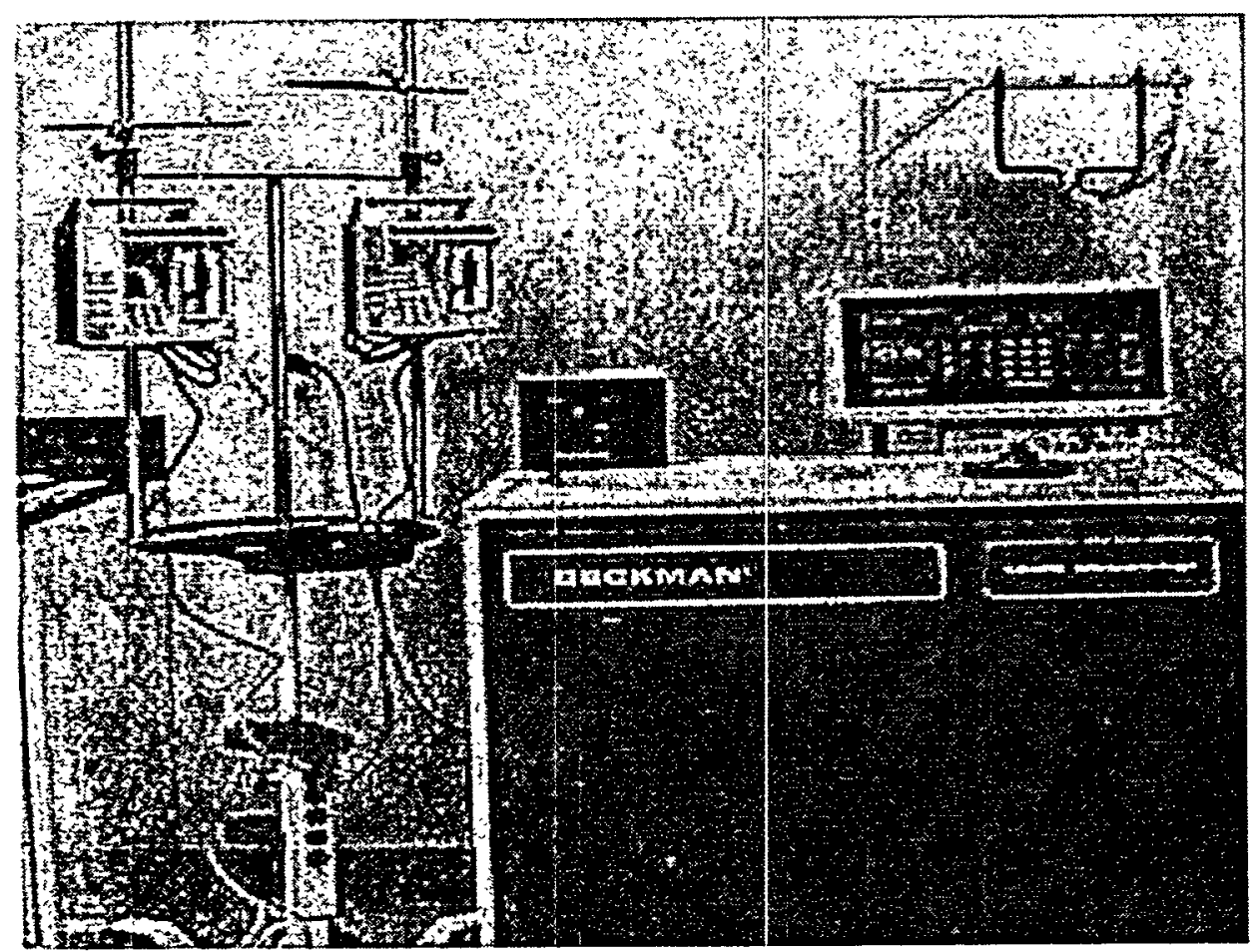

Figure 4. Picture of UFA Centrifuge 


\section{RESULTS}

\section{$\underline{\text { Permeability Results }}$}

Permeability test results are summarized in Table III:

Table II. Waste Form Permeabilities

\begin{tabular}{|c|c|c|c|c|c|}
\hline $\begin{array}{l}\text { Sample } \\
\text { Numbe }\end{array}$ & $\begin{array}{l}\text { Sample } \\
\text { Description } \\
\end{array}$ & $\begin{array}{c}\text { Falling Head } \\
\text { Permeability } \\
(\mathrm{cm} / \mathrm{s})\end{array}$ & $\begin{array}{l}\text { E-Area } \\
\text { WAC }\end{array}$ & $\begin{array}{l}\text { Centrifuge } \\
\text { Permeability } \\
(\mathrm{cm} / \mathrm{s})\end{array}$ & $\begin{array}{l}\text { E-Area } \\
\text { WAC }\end{array}$ \\
\hline 1 & $\begin{array}{l}\text { Simulant } \\
\text { with } 10 \text { wt } \% \\
\mathrm{NaCl} \text { solution }\end{array}$ & $<1 \times 10^{-10}$ & Pass & $1.69 \times 10^{-9}$ & Pass \\
\hline 2 & $\begin{array}{l}\text { Simulant } \\
\text { with } 30 \text { wt \% } \\
\mathrm{NaCl} \text { solution }\end{array}$ & $3.2 \times 10^{-9}$ & Pass & $3.05 \times 10^{-8}$ & Fail \\
\hline 3 & $\begin{array}{l}\text { Purex blow } \\
\text { crete with } 1 \text { wt } \% \\
\text { solids solution }\end{array}$ & $1.9 \times 10^{-9}$ & Pass & * & $\begin{array}{l}\text { Projected } \\
\text { Failure }\end{array}$ \\
\hline 4 & $\begin{array}{l}\text { Purex blow } \\
\text { crete with } 40 \text { wt } \% \\
\text { solids solution }\end{array}$ & $4.8 \times 10^{-8}$ & Fail & $*$ & $\begin{array}{l}\text { Projected } \\
\text { Failure }\end{array}$ \\
\hline 5 & Purex ashcrete & $<10^{-10}$ & Pass & $*$ & $\begin{array}{l}\text { Projected } \\
\text { Pass }\end{array}$ \\
\hline 6 & $\begin{array}{l}\text { CIF Plant Purex } \\
\text { ashcrete }\end{array}$ & $<10^{-10}$ & Pass & $*$ & $\begin{array}{l}\text { Projected } \\
\text { Pass }\end{array}$ \\
\hline
\end{tabular}

* Not performed because vendor does not have license for handling radioactive material.

Compressive Strength

Compressive strengths of the first five samples were greater than 700 psi using the penetrometer method. 


\section{CONCLUSIONS}

All samples prepared in the laboratory met the E- Area WAC compressive strength requirement of $500 \mathrm{psi}$. The CIF ashcrete sample prepared in the laboratory and an actual Ashcrete Plant sample (June 1999) both met the E-Area WAC for permeability. The permeabilities of both ashcrete samples were only measured by the falling head method. The correlation determined to compare the two methods implies that the ashcrete will also meet the $1 \times 10^{-8} \mathrm{~cm} / \mathrm{sec}$ requirement.

CIF blowcrete made with 1 wt \% total solids blowdown solution met the disposal WAC when measured with the falling head method but did not meet the $1 \times 10^{-8} \mathrm{~cm} / \mathrm{sec}$ criteria using the correlation to determine the centrifuge method result. Blowcrete made with concentrated scrubber solution containing $40 \mathrm{wt}$. \% total solids did not meet the permeability requirements with either method.

As the soluble salt loading in a cement-based waste form increases, the permeability increases. This was observed in the simulant samples in Sample 1 and 2 and in actual blowcrete waste in samples 3 and 4 . The phenomena occurs because water flowing through the solid waste form dissolves away the salt and thereby opens the porosity.

Based on the limited samples tested, results obtained by the centrifuge method were one order of magnitude higher (10x more permeable) than those obtained by the falling head method.

Differences in the methods include: 1) sample size and sample preparation, 2) pressure applied to the sample and permeant fluid, 3) time to achieve steady state. In addition, the method of saturating the samples was different in the two laboratories making these measurements.

Sources of error for both methods include: 1) discrepancies in the actual surface area versus the assumed surface area. In the falling head method, care must be taken to prevent epoxy from plugging pores in the thin disk-shaped samples. 2) discrepancies in the degree of saturation of the samples tested. Cement-based waste forms are difficult to saturate because a large percentage of the pores are very small. Lack of saturation will result in lower values. Consequently, determination of the degree of saturation must be measured for each sample after the permeability measurement is made. The degree of saturation should be reported along with the permeability measurement.

Either method of measuring permeability is acceptable for qualifying the $\mathrm{CIF}$ ashcrete and blowcrete for E-Area disposal. The centrifuge method should be used if available because it is a whole body method. Less end effects are encountered. 


\section{RECOMMENDATIONS}

Additional samples should be tested to confirm the correlation between the centrifuge and falling head results. In addition, all permeability results should be reported as a function of the degree of saturation of the sample used in the test.

Since blowcrete waste forms do not meet WAC permeability requirements, formulation modifications should be considered if the current operation of sending the scrubber solution to ETF is no longer possible. Additional testing is required to determine the maximum salt loading in blowcrete which will result in waste forms that meet the disposal WAC. Currently, waste forms made with $1 \mathrm{wt}$. \% blowdown solution pass permeability requirements using the falling head method but fail the permeability requirement using the correlation to determine the centrifuge permeability.

\section{QUALITY ASSURANCE}

Quality Assurance testing was conducted in accordance with SRS procedures. Results are recorded in Laboratory Notebook WSRC-NB-96-633. Work Authorization Document 112939 authorized this study ${ }^{4}$. WSRC-RP-99-00267 is the Technical Task Plan that details the work to be performed during the study ${ }^{5}$. WSRC-RP-99-00268 covers the Quality Assurance Plan for work activities ${ }^{6}$.

Centrifuge analyses performied by UFA Ventures have been accepted to ASTM D18.21 Subcommittee on Ground Water.

\section{REFERENCES}

1. "Low -Level Radioactive Waste Acceptance Criteria, WSRC Manual 1S, Procedure 3.17.

2. J.R. Cook, A.D. Yu, "Radiological Performance Assessment of Trench Disposal of CementStabilized Wasteforms (U)", Rev. 0, WSRC-RP-94-218, April 15, 1994.

3. B. W. Walker, "Procedure for the Operation of the Permeameter," Manual 12.1, Procedure IWT-OP-128, June, 1, 1999.

4. J. Simpson, "Work Authorization Document 112939," October, 7, 1998.

5. B. W. Walker, "Technical Task Plan for Developing a Method for Measuring Permeability (U)," WSRC-RP-99-00267, Rev. 0, March 22, 1999.

6. B. W. Walker, "Quality Assurance Plan for Developing a Method for Measuring Permeability (U),"WSRC-RP-99-00268, Rev. 0, March 22, 1999. 
WSRC-TR-99-00239

July 20, 1999

Page Al -1

\section{Appendix 1.}

\section{Characterization of Incinerator Waste}




\section{Off Gas Scrubber Solution (Blowdown) Characterization}

Soluble solids were $1 \%(\mathrm{w} / \mathrm{v})$. Insoluble solids were $0.2 \%(\mathrm{w} / \mathrm{v})$. Most of the solids ( $>99 \%$ ) were soluble in a hot $30 \% \mathrm{NaOH}$ solution. The bulk of the insolubles are likely alumina, silica, and probably titanium dioxide. There was no detectable soluble mercury. The density of the blow down was $1.01 \mathrm{~g} / \mathrm{ml}$ and the $\mathrm{pH}$ was 7.5 .

Gross alpha was $539 \mathrm{dpm} / \mathrm{ml}$

Gross beta was $240 \mathrm{dpm} / \mathrm{ml}$

Gross gamma was $154 \mathrm{dpm} / \mathrm{ml}$

Tritium was $1302 \mathrm{dpm} / \mathrm{ml}$

Gamma Contributors

$\underline{\text { Activity }}$

$\begin{array}{lc}3.85 \mathrm{pCi} / \mathrm{ml} & \mathrm{K}-40 \\ 1.31 \mathrm{pCi} / \mathrm{ml} & \mathrm{Co}-60 \\ 226 \mathrm{pCi} / \mathrm{ml} & \mathrm{Cs}-137 \\ 2.52 \mathrm{pCi} / \mathrm{ml} & \mathrm{Eu}-154 \\ 7.69 \mathrm{pCi} / \mathrm{ml} & \mathrm{Am}-241\end{array}$

Scrubber Solution (Blow down) Characterization

$\begin{array}{llll}\text { Component } & \text { (mg/liter) } & \text { Component } & \text { (mg/liter) } \\ \text { Silver } & <0.003 & \text { Manganese } & 0.712 \\ \text { Aluminum } & <0.060 & \text { Molybdenum } & 0.776 \\ \text { Arsenic } & 0.024 & \text { Sodium } & 2459 \\ \text { Boron } & 7.75 & \text { Nickel } & 0.075 \\ \text { Barium } & 0.085 & \text { Lead } & 0.037 \\ \text { Beryllium } & <0.0004 & \text { Selenium } & <0.015 \\ \text { Calcium } & 39.16 & \text { Antimony } & 10.64 \\ \text { Cadmium } & 0.032 & \text { Silicon } & 69.5 \\ \text { Chromium } & 0.009 & \text { Strontium } & 0.065 \\ \text { Cesium } & <10 & \text { Thorium } & <0.50 \\ \text { Copper } & 1.66 & \text { Titanium } & <0.001 \\ \text { Iron } & 0.252 & \text { Thallium } & <0.015 \\ \text { Potassium } & 92.53 & \text { Uranium } & <0.15 \\ \text { Magnesium } & 12.26 & \text { Vanadium } & 0.091 \\ \text { Zinc } & 2.43 & \text { Zirconium } & <0.035 \\ \text { Chloride } & 988 & \text { Sulfate } & 2050 \\ \text { Carbonate } & 105 & & \end{array}$




\section{Ash Characterization}

The ash was wet quenched and contained $45+/-15 \%$ quench water. Ash used in this study was drained of excess water which resulted in a water content of about $25 \%$. The $\mathrm{pH}$ of the water in contact with the ash was 10.6.

Ash Characterization

$\begin{array}{llll}\text { Component } & \text { (mg/liter) } & \text { Component } & \text { (mg/liter) } \\ \text { Mercury } & 0.0042 & \text { Selenium } & 0.255 \\ \text { Silver } & 0.226 & \text { Antimony } & 29.7 \\ \text { Arsenic } & 6.96 & \text { Thallium } & 0.416 \\ \text { Barium } & 238 & \text { Copper } & 646 \\ \text { Beryllium } & 0.266 & \text { Iron } & 6400 \\ \text { Cadmium } & 2.57 & \text { Manganese } & 153 \\ \text { Chromium } & 16.9 & \text { Sodium } & 5450 \\ \text { Nickel } & 87.4 & \text { Titanium } & 3.9 \\ \text { Lead } & 44.8 & \text { Zinc } & 846 \\ \text { Cobalt } & 3.43 & & \end{array}$


WSRC-TR-99-00239

July 20, 1999

Page A2 -1

Appendix 2.

Permeability Calculations for Waste Forms 


\section{Calculations}

Sample 1) Portland cement made with $10 \% \mathrm{NaCl}$ simulant Permeability

$\mathrm{L}=$ length of sample $=0.793 \mathrm{~cm}$

$\mathrm{D}=$ diameter of sample $=3.075 \mathrm{~cm}$

$\mathrm{R}=0.5 \times \mathrm{D}=1.54$

$\mathrm{A}=3.14 \mathrm{rx}=7.42 \mathrm{~cm}^{2}$

Manometer height $1=\mathrm{h} 1=2 \mathrm{~cm}$

Manometer height $2=\mathrm{h} 2=3 \mathrm{~cm}$

Average manometer height $=\mathrm{h}=(\mathrm{h} 1+\mathrm{h} 2) / 2=2.5 \mathrm{~cm}$

Pressure gauge 1 reading $=\mathrm{P} 1=10 \mathrm{psig}$

Pressure gauge 2 reading $=\mathrm{P} 2=0 \mathrm{psig}$

$\mathrm{H}=(\mathrm{P} 1-\mathrm{P} 2) 70.31+\mathrm{h}=(10-0) 70.31+2.5=705.6$

$\mathrm{Q}=$ volume collected $/$ collection time $=0 \mathrm{~cm}^{3} / 12 \times 3600$ seconds $=0 \mathrm{~cm}^{3} / \mathrm{s}$

Solve for $Q$ if $K=1 \times 10^{-10} \mathrm{~cm} / \mathrm{s}$

If Permeability $=\mathrm{K}=\mathrm{QL} / \mathrm{AH}=(\mathrm{Q})(0.793) /(7.42)(705.6)=1 \times 10^{-10} \mathrm{~cm} / \mathrm{s}$

$\mathrm{Q}=0.0036 \mathrm{mls} / \mathrm{hr} \quad$ (this is probably the smallest flow rate that can be detected with the permeameter therefore the permeability of the sample is less than $1 \times 10^{-10} \mathrm{~cm} / \mathrm{s}$ )

Sample 2) Portland cement made with $30 \% \mathrm{NaCl}$ simulant Permeability

$\mathrm{L}=$ length of sample $=0.863 \mathrm{~cm}$

$\mathrm{D}=$ diameter of sample $=3.113 \mathrm{~cm}$

$\mathrm{R}=0.5 \times \mathrm{D}=1.56$

$\mathrm{A}=3.14 \mathrm{r} \times \mathrm{r}=7.61 \mathrm{~cm}^{2}$

Manometer height $1=\mathrm{h} 1=1.5 \mathrm{~cm}$

Manometer height $2=\mathrm{h} 2=2.5 \mathrm{~cm}$

Average manometer height $=\mathrm{h}=(\mathrm{h} 1+\mathrm{h} 2) / 2=2 \mathrm{~cm}$

Pressure gauge 1 reading $=\mathrm{P} 1=10$ psig

Pressure gauge 2 reading $=\mathrm{P} 2=0 \mathrm{psig}$

$\mathrm{H}=(\mathrm{P} 1-\mathrm{P} 2) 70.31+\mathrm{h}=(10-0) 70.31+11.35=714.45$

$\mathrm{Q}=$ volume collected $/$ collection time $=0.15 \mathrm{~cm}^{3} / 2.25 \mathrm{hrs}=1.9 \times 10^{-5} \mathrm{~cm}^{3} / \mathrm{s}$

Permeability $=\mathrm{K}=\mathrm{QL} / \mathrm{AH}=\left(1.9 \times 10^{-5}\right)(0.863) /(6.61)(705.1)=3 \times 10^{-9} \mathrm{~cm} / \mathrm{s}$ 
Sample 3) 1 weight \% total solids Scrubber Solution Permeability

$\mathrm{L}=$ length of sample $=0.921 \mathrm{~cm}$

$\mathrm{D}=$ diameter of sample $=2.89 \mathrm{~cm}$

$\mathrm{R}=0.5 \times \mathrm{D}=1.45$

$\mathrm{A}=3.14 \mathrm{rx} \mathrm{r}=6.56 \mathrm{~cm}^{2}$

Manometer height $1=\mathrm{h} 1=1.5 \mathrm{~cm}$

Manometer height $2=\mathrm{h} 2=1.4 \mathrm{~cm}$

Average manometer height $=h=(h 1+h 2) / 2=1.45 \mathrm{~cm}$

Pressure gauge 1 reading $=\mathrm{P} 1=10 \mathrm{psig}$

Pressure gauge 2 reading $=\mathrm{P} 2=0 \mathrm{psig}$

$\mathrm{H}=(\mathrm{P} 1-\mathrm{P} 2) 70.31+\mathrm{h}=(10-0) 70.31+1.45=704.55$

$\mathrm{Q}=$ volume collected $/$ collection time $=0.2 \mathrm{~cm}^{3} / 5.5 \times 3600$ seconds $=1 \times 10^{-5} \mathrm{~cm}^{3} / \mathrm{s}$

Permeability $=\mathrm{K}=\mathrm{QL} / \mathrm{AH}=\left(1 \times 10^{-5}\right)(0.921) /(6.56)(704.55)=1.9 \times 10^{-9} \mathrm{~cm} / \mathrm{s}$

Sample 4) 40 weight \% total solids Scrubber Solution Permeability

$\mathrm{L}=$ length of sample $=0.989 \mathrm{~cm}$

$\mathrm{D}=$ diameter of sample $=3.06 \mathrm{~cm}$

$\mathrm{R}=0.5 \times \mathrm{D}=1.528$

$\mathrm{A}=3.14 \mathrm{rx} \mathrm{r}=7.33 \mathrm{~cm}^{2}$

Manometer height $1=\mathrm{h} 1=2.0 \mathrm{~cm}$

Manometer height $2=\mathrm{h} 2=1.9 \mathrm{~cm}$

Average manometer height $=h=(h 1+h 2) / 2=1.95 \mathrm{~cm}$

Pressure gauge 1 reading $=\mathrm{P} 1=10 \mathrm{psig}$

Pressure gauge 2 reading $=\mathrm{P} 2=0 \mathrm{psig}$

$\mathrm{H}=(\mathrm{P} 1-\mathrm{P} 2) 70.31+\mathrm{h}=(10-0) 70.31+2.2=705.05$

$\mathrm{Q}=$ volume collected $/$ collection time $=0.9 \mathrm{~cm}^{3} / 5.5 \times 3600$ seconds $=0.00025 \mathrm{~cm}^{3} / \mathrm{s}$

Permeability $=\mathrm{K}=\mathrm{QL} / \mathrm{AH}=(0.00025)(0.989) /(7.33)(705.05)=4.8 \times 10^{-8} \mathrm{~cm} / \mathrm{s}$ 
Sample 5) Ash waste form prepared at SRTC Permeability

$\mathrm{L}=$ length of sample $=0.815 \mathrm{~cm}$

$\mathrm{D}=$ diameter of sample $=3.12 \mathrm{~cm}$

$\mathrm{R}=0.5 \times \mathrm{D}=1.56$

$\mathrm{A}=3.14 \mathrm{r} \times \mathrm{r}=7.64$

Manometer height $1=\mathrm{h} 1=1.0 \mathrm{~cm}$

Manometer height 2 $=\mathrm{h} 2=0.9 \mathrm{~cm}$

Average manometer height $=\mathrm{h}=(\mathrm{h} 1+\mathrm{h} 2) / 2=.95 \mathrm{~cm}$

Pressure gauge 1 reading $=\mathrm{P} 1=10 \mathrm{psig}$

Pressure gauge 2 reading $=\mathrm{P} 2=0 \mathrm{psig}$

$\mathrm{H}=(\mathrm{P} 1-\mathrm{P} 2) 70.31+\mathrm{h}=(10-0) 70.31+.95=704.05$

$\mathrm{Q}=$ volume collected $/$ collection time $=0 \mathrm{~cm}^{3} / 5.08 \times 3600$ seconds $=0 \mathrm{~cm}^{3} / \mathrm{s}$

Solve for $Q$ if $K=1 \times 10^{-10} \mathrm{~cm} / \mathrm{s}$

If Permeability $=\mathrm{K}=\mathrm{QL} / \mathrm{AH}=(\mathrm{Q})(0.815) /(7.64)(704.05)=1 \times 10^{-10} \mathrm{~cm} / \mathrm{s}$

$\mathrm{Q}=0.00238 \mathrm{mls} / \mathrm{hr} \quad$ (this is less than the smallest flow rate that can be detected with the permeameter in Sample 1 therefore the permeability of the sample is less than $1 \times 10^{-10}$ $\mathrm{cm} / \mathrm{s})$

Sample 6) Actual plant ashcrete waste form Permeability

$\mathrm{L}=$ length of sample $=1.55 \mathrm{~cm}$

$\mathrm{D}=$ diameter of sample $=3.25 \mathrm{~cm}$

$\mathrm{R}=0.5 \times \mathrm{D}=1.625$

$\mathrm{A}=3.14 \mathrm{rxr}=8.29$

Manometer height $1=\mathrm{h} 1=1.1 \mathrm{~cm}$

Manometer height $2=\mathrm{h} 2=1.0 \mathrm{~cm}$

Average manometer height $=\mathrm{h}=(\mathrm{h} 1+\mathrm{h} 2) / 2=1.0 \mathrm{~cm}$

Pressure gauge 1 reading $=\mathrm{P} 1=10 \mathrm{psig}$

Pressure gauge 2 reading $=\mathrm{P} 2=0 \mathrm{psig}$

$\mathrm{H}=(\mathrm{P} 1-\mathrm{P} 2) 70.31+\mathrm{h}=(10-0) 70.31+1.0=704.1$

$\mathrm{Q}=$ volume collected/collection time $=0 \mathrm{~cm}^{3} / 5.0 \times 3600$ seconds $=0 \mathrm{~cm}^{3} / \mathrm{s}$

Solve for $\mathrm{Q}$ if $\mathrm{K}=1 \times 10^{-10} \mathrm{~cm} / \mathrm{s}$

If Permeability $=\mathrm{K}=\mathrm{QL} / \mathrm{AH}=(\mathrm{Q})(1.55) /(8.29)(704.1)=1 \times 10^{-10} \mathrm{~cm} / \mathrm{s}$

$\mathrm{Q}=3.8 \times 10^{-7} \mathrm{mls} / \mathrm{hr}$ (this is less than the smallest flow rate that can be detected with the permeameter in Sample 1 therefore the permeability of the sample is less than $1 \times 10^{-10}$ $\mathrm{cm} / \mathrm{s}$ ) 
Appendix 3.

ELE Permeability Procedure 
SRTC-TR-99-00239

July 20, 1999

Page A3 -2

\section{PROCEDURE FOR THE OPERATION OF THE \\ PERMEAMETER (U)}

\subsection{PURPOSE}

The Consolidated Incinerator Facility (CIF) at the Savannah River Site (SRS) burns low level radioactive and mixed waste. Ash and scrubber system waste streams are generated during the incineration process and are currently solidified with Portland cement. Magnesium Phosphate Ceramic and Slag Cement technologies were tested to evaluate their effectiveness to stabilize High Solids and scrubber solution waste streams. To meet Waste Acceptance Criteria permeability of the solid waste forms made with ash and scrubber solution must be determined using a permeameter.

Presently Purex waste containing trace amounts of Plutonium and other radionuclides is being burned and solidified with Portland cement. Permeability of solid waste forms from this waste stream must also be determined to meet Solid Waste Acceptance Criteria.

\subsection{SCOPE}

2.1 This procedure applies to personnel operating the Permeameter.

2.2 The Permeameter has a tank for storing water that is pressurized by a line attached to a laboratory air outlet. The pressure of the air is adjusted by using a pressure regulator. A core sample of the solid waste form is glued into a sample holder which is attached to the apparatus.

2.3 Permeability is determined by measuring the amount of water that flows through the sample over a given time period at a regulated pressure.

\subsection{PRECAUTIONS AND LIMITATIONS}

3.1 Perform radioactive hood work per the requirements listed on the Radioactive Work Permit. 
3.2 When attaching sample holder to apparatus make sure gaskets seal without leaking. Test for gasket leaks with hood window lowered, shield in place, and under low pressure to avoid spraying radioactive liquid out of hood.

3.3 Attach a containment hose around hose from water tank to keep leaks within hood containment.

3.4 Be careful to not tear gloves during sample preparation sawing and sanding to avoid contamination hazards

\subsection{PREREQUISITES ACTIONS}

4.1 Remove solid waste core samples from sample bottles. Flatten the top and bottom surface using a hack saw blade and sand paper. Measure the length and diameter of the sample in centimeters and record on data sheet in attachment 2.

4.2 Glue the solid waste core into the sample holder using epoxy resin placed in a syringe. Try to glue only the sides of the sample to the inner surface of the sample holder without getting excess glue on the surface of the sample.

4.3 Samples are saturated by immersing in water for 72 hours in a container and applying house vacuum line.

\subsection{PROCEDURE}

5.1 Close air valve $2 \mathrm{~A}$ on permeameter.

5.2 Check permeameter pressure gauge $4 \mathrm{~A}$ at pressure regulator to verify 0 psig. If system not depressurized contact Researcher before proceeding.

5.3 Close valve S1 on sample holder head assembly.

5.4 Close valve $2 \mathrm{C}$ on exit of bottom of sample holder head assembly.

5.5 Close valve $\mathrm{T} 1$ on permeameter tank.

5.6 Close valve 2B on tank manometer tube. 
5.7 Position the sample holder to the permeameter to contact sealing gaskets on sample assembly and tighten retaining bolts.

5.8 Open valve S1 on sample assembly.

5.9 Check for leaks by placing hood window as low as possible, taping a plastic bag as a shield in front of the permeameter, applying 2 to 5 psig pressure to system by opening Valve $2 \mathrm{~A}$, and adjusting the pressure regulator.

5.10 Close valve 2A if leaks are found and perform steps 5.11, 5.12, 5.13, 5.14, 5.15, and 5.16. If no leaks are found close valve $2 \mathrm{~A}$ and skip steps 5.11 through 5.16 .

5.11 Close valve S1.

5.12 Position the sample holder to the permeameter to contact sealing gaskets on sample assembly and tighten retaining bolts.

5.13 Open valve S1.

5.14 Check for leaks by placing hood window as low as possible, taping a plastic bag as a shield in front of the permeameter, applying 2 to 5 psig pressure to system by opening Valve $2 \mathrm{~A}$ and adjusting the pressure regulator.

5.15 Repeat steps 5.10 through 5.14 until leaks are stopped.

5.16 Turn off valve $2 \mathrm{~A}$ after leaks have been stopped.

5.17 Add water to buret tube attached to sample holder assembly until close to midpoint level is achieved.

5.18 Add small amount of oil to buret tube on sample holder assembly to stop water evaporation.

5.19 Open air valve 2A and adjust pressure regulator to achieve pressure setting required by researcher.

5.20 Open valve $S 1$ on sample holder assembly.

5.21 Wait 30 minutes to let air in system disappear.

5.22 Close valve S1.

5.23 Close valve 2A.

5.24 Adjust pressure regulator to depressurize system. 
Open valve $2 \mathrm{~B}$ on tank manometer tube.

5.26 Determine tank level by looking at water level in tank manometer tube.

5.27 If level is not around mid point of tank level remove valve $\mathrm{T} 1$ on permeameter tank, insert small funnel, and add water until level is around midpoint.

5.28 Measure distance from top of tank manometer tube level to top of sample holder manometer tube level and record as $\mathrm{hl}$ on data sheet.

5.29 Reattach and close valve T1 to permeameter tank.

5.30 Close valve 2B.

5.31 Open valve 2A and adjust pressure regulator to achieve pressure setting required by researcher.

5.32 Open valve S1 on sample holder, record buret level as V1 on data sheet, and exact time of day $\mathrm{S} 1$ is opened as $\mathrm{T} 1$ on data sheet.

5.33 Record pressures on gauges $4 \mathrm{~A}$ as $\mathrm{P} 1$ and $4 \mathrm{~B}$ as $\mathrm{P} 2$ on data sheet.

5.34 After period of time required by researcher close valve S1, record exact time valve $S 1$ is closed on data sheet as T2, and buret level in sample holder as V2 on data sheet.

5.35 Close valve 2A and adjust pressure regulator to allow PG4A to read $0 \mathrm{psig}$.

5.36 Open valve $2 \mathrm{~B}$ on tank manometer tube.

5.37 Measure distance from top of tank manometer tube level to top of sample holder manometer tube level and record as $\mathrm{h} 2$ on data sheet.

5.38 Close valve 2B on tank manometer tube.

5.39 Perform the Permeability calculations using data from the data sheet.

$\mathrm{R}=.5 \times \mathrm{D}$

$\mathrm{A}=3.14 \times \mathrm{R} \times \mathrm{R}$

$\mathrm{h}=(\mathrm{h} 1+\mathrm{h} 2) / 2$

$\mathrm{V}=\mathrm{V} 2-\mathrm{V} 1$

$\mathrm{T}=(\mathrm{T} 2-\mathrm{T} 1) \times 3600$

$Q=V / T$

$\mathrm{H}=(\mathrm{PI}-\mathrm{P} 2) 70.31+\mathrm{h}$

$\mathrm{K}=$ Permeability $=\mathrm{QL} / \mathrm{AH}$ 
SRTC-TR-99-00239

July 20,1999

Page A3-6

\subsection{RECORDS}

6.1 Data will be recorded on the data sheet and in a Lab Notebook.

\subsection{REFERENCES}

None.

\subsection{ATTACHMENTS}

Attachment 1. Permeameter Sketch

Attachment 2. Data Sheet 


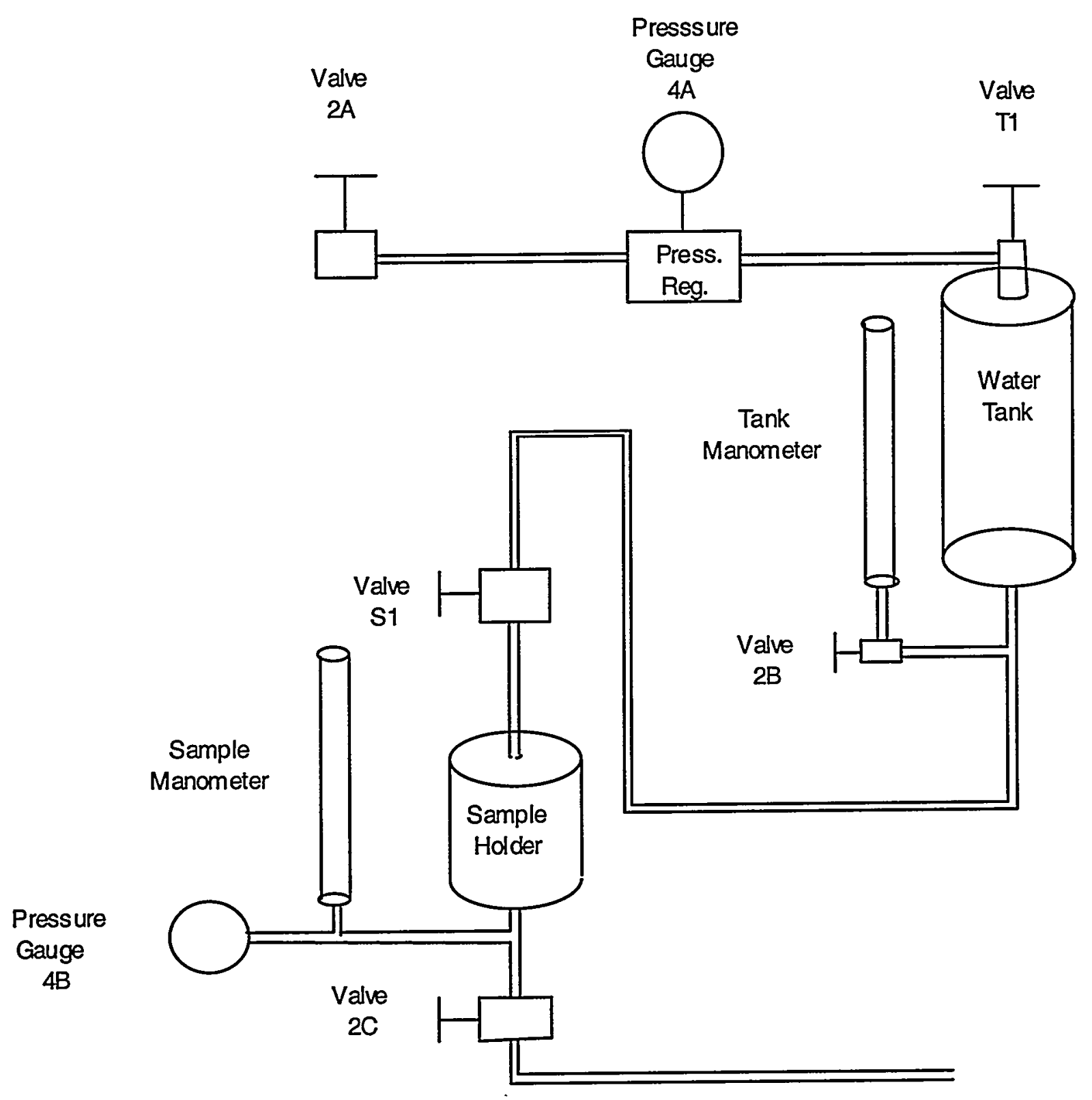

Attachment 1. Permeameter Sketch 
Attachment 2. Data Sheet

Step $4.1, \mathrm{~L}=$

Step 4.1, D = — $\mathrm{cm}$

Step $5.28, \mathrm{hl}=$

Step 5.32, V1 = _ $\mathrm{mls}$

Step 5.32, $\mathrm{T} 1=$

Step 5.33, P1 = _ psig

Step 5.33, P2 = _ psig

Step 5.34, V2 = _ $\mathrm{mls}$

Step $5.34, \mathrm{~T} 2=\ldots$ hrs

Step 5.37, h2 = 